\title{
GCU
}

Glasgow Caledonian

University

University for the Common Good

\section{Social innovation, financialisation and commodification: a critique of social impact} bonds

Sinclair, Stephen; McHugh, Neil; Roy, Michael J.

Published in:

Journal of Economic Policy Reform

DOI:

$10.1080 / 17487870.2019 .1571415$

Publication date:

2021

Document Version

Author accepted manuscript

Link to publication in ResearchOnline

Citation for published version (Harvard):

Sinclair, S, McHugh, N \& Roy, MJ 2021, 'Social innovation, financialisation and commodification: a critique of social impact bonds', Journal of Economic Policy Reform, vol. 24, no. 1, pp. 11-27. https://doi.org/10.1080/17487870.2019.1571415

\section{General rights}

Copyright and moral rights for the publications made accessible in the public portal are retained by the authors and/or other copyright owners and it is a condition of accessing publications that users recognise and abide by the legal requirements associated with these rights.

Take down policy

If you believe that this document breaches copyright please view our takedown policy at https://edshare.gcu.ac.uk/id/eprint/5179 for details of how to contact us. 


\title{
Social Innovation, Financialisation and Commodification: A Critique of Social Impact Bonds
}

\author{
Stephen Sinclair ${ }^{1}$, Neil McHugh ${ }^{1}$ and Michael J Roy ${ }^{1}$ \\ ${ }^{1}$ Yunus Centre for Social Business and Health, Glasgow Caledonian \\ University, UK \\ stephen.sinclair@gcu.ac.uk (corresponding author) \\ neil.mchugh@gcu.ac.uk \\ michael.roy@gcu.ac.uk
}

\begin{abstract}
Despite a lack of evidence of their effectiveness there is increasing enthusiasm for Social Impact Bonds (SIBs) from diverse political perspectives across the world. This paper argues that while SIBs may potentially be applicable to some technical policy interventions which address relatively simple conditions, they are inappropriate for the complex conditions characterising wicked social problems. Enthusiasm for and over-extension of SIBs reflects a simplistic view of 'evidence-based' policy. More fundamentally, SIBs commodify citizens and redefine service users as problems and potential revenue sources rather than conscious agents. SIBs therefore exemplify a prevalent ideology of marketisation and financialisation in social policy.
\end{abstract}

\section{Authors' Pre-Publication Version}

To cite:

Sinclair, S., McHugh, N. and Roy, M.J. (2019) 'Social Innovation, Financialisation and Commodification: A Critique of Social Impact Bonds'. Journal of Economic Policy Reform 


\section{Social Innovation, Financialisation and Commodification: A Critique of Social Impact Bonds}

\section{Introduction}

Despite concerns and a lack of evidence for their effectiveness, there is widespread enthusiasm for Social Impact Bonds (SIBs). In theory, SIBs incentivise private investors to finance innovative social policies by providing dividends if these initiatives outperform conventional interventions. SIBs are regarded by advocates as a 'win-win' situation for taxpayers and private investors (Chou, 2016). As one American Congressional official put it 'the Republicans like this because it lets the private sector get access to public social welfare dollars and the Democrats like it because it might increase public investment in social welfare' (Morely, 2017).

SIBs are undoubtedly an imaginative financial innovation and the attention and enthusiasm they have generated transcends geographic, cultural and political divisions (Dear et al, 2016). There are estimated to be between 89-160 SIBs already operating or under development in 19 countries, and they are being adapted to finance international development activity in the form of Development Impact Bonds (Ronicle et al, nd; Social Finance, nd). While the scale of SIBs-funded provision is currently relatively small, significant hopes and political capital have been invested in them and their potential implications for future economic and social policy are considerable. This is particularly the case in the UK, which has pioneered the most 'enabling environment' for SIBs in the world (Loxley and Puzyreva, 2015: 8). The UK implemented the first ever SIB in 2010, and the Prime Minister has boasted of Britain's 'global leadership' in their development (May, 2017). There are currently 42 SIBs operating in the UK (Carter, 2016). The British government allocated $£ 25$ million funding for SIBs in its Spending Review and Autumn Statement in November 2015, and has committed $£ 105$ million to develop SIBs in such areas as tackling homelessness, providing mental health services and schemes for unemployed young people (Murray and Gripper, 2016)i. The UK Government Outcomes Lab has created a SIBs Centre of Excellence, and the UK Minister for Civil Society predicted that SIBs would 'revolutionise' third sector and social service funding and declared his hope that the SIBs market in Britain would reach $f 1$ billion by 2020 (Weakley, 2016). 
Although several practical guides have been developed by SIBs enthusiasts (e.g. UK Government, nd), neither their basic principles nor implications have been subject to the level of scrutiny and critique they require. Furthermore, a recent evaluation concluded that 'we cannot demonstrate, on the basis of existing evaluation evidence, that SIBs fulfil the many and varied promises that their champions make for them' (Carter and FitzGerald, 2018). In the absence of compelling supporting evidence, 8 years after their initial launch, it is reasonable to ask what the basis might be for the vocal enthusiasm propelling SIBs across geographic and political frontiersii.

This paper contributes to such a critique by analysing and challenging some of the underlying normative and policy assumptions upon which SIBs rest. We argue that SIBs have at best a limited (and as yet unproven) applicability to particular types of technical social policy interventions but they are singularly unsuited to deal effectively with wicked social problems which require transformational interventions. 'Wicked' problems are those which are not resolvable by direct intervention due to the multiple, compounding factors involved, contested ideas of their nature and causality, and the challenges of complexity (as discussed in Section 5 below). This distinction between technical and transformational measures is described in Section 3 below, following a brief description of how SIBs operate and summary of some of the controversial issues they raise.

Section 4 argues that much of the support for SIBs is attributable to the fact that they exemplify and extend a particular normative orientation to social welfare provision; one which has come to dominate social policy across much of the English speaking world. SIBs appear to depoliticise social policy, but the application of narrowly conceived economic principles to welfare provision is highly ideological (Kohli et al, 2012). SIBs represent a further step in the financialisation of social policy and transform service users into 'fictitious commodities'; in effect inflicting a form of ontological violence upon some highly vulnerable groups (Polanyi, 1944).

Section 5 of the article argues that one effect of this tendency has been the marginalisation of service users' voice and agency. They are reclassified as social problems to be rectified and as potential revenue sources rather than as conscious agents and citizens. The focus on performance indicators to trigger payment, which is central to SIBs, involves simplifying complex and wicked social conditions into readily measurable metrics. In contrast, truly 
transformational social innovations actively empower service users and enhance the capability of disadvantaged communities (Moulaert et al, 2005). We argue that this is best achieved by a participatory approach to service design, implementation and evaluation.

\section{Debating Social Impact Bonds}

Social Impact Bonds combine and extend the principles and practices of several recent developments in the funding and management of social policies. These include elements of public-private partnerships (Sclar, 2015), outcomes-based contracts (Dowling and Harvie, 2014) and 'payment by results' funding of social interventions (Cooper et al, 2016). In theory, SIBs involve levering private investment to fund social interventions. In practice, this investment is usually brokered by a third sector intermediary or social philanthropy agent (e.g. in the UK case, Big Society Capital, a government-funded social investor), and often underwritten by public agencies. This finance is neither a donation nor a grant but supposedly a form of investment, with potential for profitable returns and corresponding risk of loss. The logic behind SIBs is that private investors will receive a return on their investment if the initiative they fund produces outcomes which meet or exceed predetermined targets. Specifically, SIBs generate returns for investors if the funded intervention is assessed to perform measurably better than that achieved for a control group or against a baseline (usually either a standard form of service provision or the outcomes of a comparator client group). If the SIB-funded intervention does not achieve its target nor demonstrate superior performance then the funder loses their investment. If, however, the service does meet its performance targets then the funder recoups their investment and receives a dividend payment, in relation to predetermined scales (subject to an upper limit specified in the contract between the private investor, intermediary and service provider). The additional payment for superior performance is ostensibly (although of course not literally) drawn from the putative future savings made in public spending held to accrue from the attributed preventative benefits of the intervention. According to the former UK Government Minister for Civil Society, 'SIBs represent a revolution in the way government can deliver public services. They generate huge potential savings for the taxpayer, the prospect of increased revenues for charities and social enterprises and returns to social investors' (quoted in Kay, 2016). 
Other advocates of SIBs suggest that they 'have enormous potential to lead to more outcomefocused financing that focuses on preventive interventions and incentivizes collaboration' (Gardiner et al, 2016). It is also claimed that the incentive of financial returns focuses attention on improving performance and enhances transparency (Mulvaney and Kriegler, 2014). Another attribute commonly claimed for SIBs is that the upfront and secure funding they provide, and their focus on outcomes rather than prescribed inputs, encourages experimentation and innovative service provision (North, 2016). It is argued that this attention to deliverables and the bottom line, reinforced by performance monitoring, 'concentrated minds' and facilitates a commitment to continuous improvement (Centre for Public Impact, 2016). In this respect, SIBs are held to free third sector service providers from the dead hand of regulation and standardisation, and liberate them to adapt and respond to clients' needs.

However there is an alternative view which challenges this optimistic interpretation of the operation and effect of SIBs. Even enthusiastic supporters acknowledge that, several years after the first SIB was launched, there is little evidence that they in themselves (as opposed to any additional resources they might provide) actually produce more innovative provision or better outcomes than conventionally funded services (Tan et al, 2015). In addition, SIBs pose serious practical problems. They are technically difficult to commission and involve considerable transaction costs (Fraser et al, 2016). Furthermore, significant public and/or philanthropic subsidies have been required to underwrite SIBs and induce private investors who are reluctant to finance innovative and risky social interventions (Pasi, 2014). The scale of public protection against risk is considerable, with some financiers offered guarantees of returns of up to $50 \%$ of their investment (Warner, 2017). Therefore, rather than shifting risk and investment 'the public sector subsidy will have to subsidise private investors' (Joy and Shields, 2018: 685) in what amounts to a notable extension of corporate welfare (Farnsworth, 2013).

Even if it could be proven that a SIB directly contributed to future cost savings, it is likely that any such effect would depend upon sustaining at least some of the work they fund and not withdrawing this simply after immediate contracted targets have been met (Edmiston and Nicholls, 2018). There are also well known unintended and perverse outcomes which arise 
from setting specific targets and insensitive or inflexible systems of working in social policy (Davies et al, 2006: 172). In theory, SIBs sidestep this problem by adopting a 'black box' approach to interventions in which the focus is on achieving outcomes rather than prescribing particular actions. However, in practice, SIB-funded services have not been so liberating. Funders and intermediaries which commission SIBs in the UK are heavily involved in the design of the initiatives they choose to finance (Carter, 2016). Indeed, some third sector service providers have reported less flexibility in how they are able to deliver services, and increased oversight, accountability and a substantial administrative burden imposed by very hands-on investors (Edmiston and Nicholls, 2018).

Despite claims to the contrary, few SIBs address the actual causes of problems, but focus instead on their symptoms and manifestations - where they occur and whom they impact upon. Neither do SIBs necessarily move interventions 'upstream' to tackle the causes of social problems; they simply throw a rather leaky lifebelt that might help some people keep their heads above the water while they are still swept away by more powerful, deeper currents.

For these reasons, and despite the enthusiasm (or hype) for them, no large scale SIBs have yet been commissioned (Carter, 2016). They have in fact been relatively small in scale in terms of capital and beneficiaries. Neither have they focused on particularly innovative interventions; in fact almost all have minimized investors' risk by relying upon tried and trusted policies with a strong evidence base (Whitfield, 2015: i). There is little indication of any compelling demand for SIBs among third sector organisations, many of which possess neither the necessary financial skills nor systems to manage such investments (Murray and Gripper, 2016). Above all, it is ironic that there remains no significant evidence supporting an initiative which ostensibly focuses so much on outcomes and impact (Joy and Shields, 2018). Consequently, their champions are still promoting the as yet unproven 'potential' of SIBS (Gustafsson-Wright, et al 2017). However, some third sector representatives in the UK have cautioned against the government's ambitious expansion plans, with New Philanthropy Capital arguing that 'there is a risk that too much is being expected of them too soon' (Radojev, 2016).

\section{Technical v Transformational Social Policies}

The well documented challenges involved in implementing and evaluating SIBs raise more profound issues which SIBs raise set boundaries to their viability (McHugh et al, 2013; Sinclair 
et al, 2014). In particular two issues which SIBs raise in relation to the 'attribution problem' in policy evaluation highlight their limitations (Blamey and Mackenzie, 2007). Firstly, SIBs are inhibited by the difficulty of understanding causality. Secondly, there are issues raised by the multiple stakeholder collaboration involved in the complex interventions tackling wicked social problems which SIBs ostensibly address.

Grimm et al (2013) identify two broad contrasting ontological approaches to evaluation. The first derives from a positivist tradition and is exemplified by elements of the 'evidence-based policy movement' (Pearce and Raman, 2014). Some champions of SIBs closely align them to evidence-based policy making (Dear et al, 2016). This approach regards randomized controlled trials as the 'gold standard' of scientific evidence; seeing this technique as 'the only methodology that eliminates the possibility that impact could be attributed to something other than the intervention' (Gardiner et al, 2016). Advocates of this approach bemoan the fact that most SIBs (and in fact most social policy interventions) are not assessed using randomised control trials but use instead what they regard as less rigorous methods (Goldacre, 2011). SIBs raise an anomaly in this regard: how to reconcile a randomised control trial (which requires variables to be delineated in advance and then carefully compared) with a supposedly 'black box' and open approach to intervention?

In contrast to this positivist tradition a range alternative approaches believe, for various reasons, that there are limits to the viability of this version of evidence-based policy. These perspectives include interpretative, phenomenological and action-oriented approaches, among others (Silverman, 2000). Such approaches often use abductive reasoning based on incomplete and imperfect information to infer the most plausible diagnosis and future actions in response to complex social conditions. These perspectives regard policy as 'a less linear, more iterative process in which the aspirations of policy makers should be more modest' (Grimm et al, 2013: 449). This position challenges the plausibility of specifying the kind of outcome measures required by payment-by-results policy approaches which are central to SIBs.

The validity and relative practical viability of applying these contrasting approaches to evaluation depends upon the nature of the issue and intervention addressing it. A heuristic distinction can be drawn between what might be called technical and transformative interventions. An example of the former would be a project to increase the uptake of 
vaccinations. The Delmarva Young Blood Sustainability project - which aims to increase blood

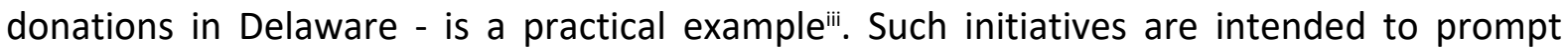
relatively simple behavioural responses and encourage minor uncomplicated changes rather than any deeper reconsideration of circumstances, meanings and actions. Their effects may be measured more or less directly by counting selected items or incidents (e.g. client uptake or throughput numbers), rather than deriving indirect proxies and indicators. Such initiatives seek to encourage rather straightforward behavioural changes, which may be amenable to 'nudge' style initiatives or simple incentives and, in theory, perhaps could be evaluated using randomised control trials (Thaler and Sunstein, 2008). The SIB developed by Lambeth Council in London to encourage children with special educational needs to use public transport is an example of such an initiative (Bridges Fund Management, 2017).

In contrast, transformative interventions seek to generate a more profound reformulation of the dynamic between conditions and action, and therefore must engage the agency of the service 'recipient', or properly speaking, the actor. Transformative interventions address complex problems with the aim of reducing or ameliorating wicked conditions. Examples of such interventions include 'thick' employment training and labour market support programmes - as opposed to 'thin' workfare schemes intended to reduce the unemployment

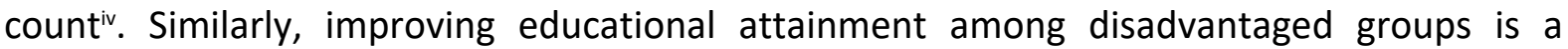
transformational challenge - one currently being funded by SIB in the German city of Mannheim. Other complex conditions requiring transformational responses which have been targeted by SIBs projects including reducing obesity (in Israel) and urban regeneration or social inclusion projects.

To be effective, such interventions must be situational, relational and context-specific. The nature of transformative interventions implies that the form and manner of the interaction, and the culture of organisations and systems involved in delivering them, are decisive in shaping relationships. At the heart of a transformative social policy intervention, which genuinely seeks to enhance a citizen's capability, is the recognition that policy is a relationship between purposive agents rather than a scheme implemented upon a passive object. Therefore, effective transformative interventions must be developed interactively with those they are intended to help. This is confirmed by extensive research on the significance of the policy implementation process; or what really ought to be called the delivery / reception 
relationship (e.g. Fuertes and Lindsay, 2015; Lipsky, 2010). This research demonstrates that how a service is provided and perceived by users is an inextricable and determinant feature of its reception and effects. A transformational social intervention must engage with the mind and identity of those whom it seeks to support. Their effectiveness depends upon working with rather than doing things to the target group. Numerous SIBs have been misguidedly applied to such complex challenges and relationships without, as yet, compelling evidence of their effectiveness (Ronicle, et al, 2016).

The ontological and methodological limitations of randomised control trials, and the cruder strands of the evidence-based policy movement, derive from the assumption that although social policies might be complicated, they can nevertheless be reframed in mechanistic terms (Dowling and Harvie, 2014: 871). The 'focus on data, outcomes and measurement' promoted by SIBs lobbyists (Dear et al, 2016: 3) fails to grasp that human interaction is relational, subjective and generates emergent complexities. The scientistic and technocratic model of inputs-producing-outcomes, upon which randomised control trials depend, might be applicable to simple technical processes which do not involve significant engagement with human agency. However they are inadequate in themselves to produce the insights required to understand (let alone change) human interactions and social conditions (McHugh et al, 2017).

The ultimate aspiration of the 'what works' approach to social policy is to identify best practice and effective techniques. This is a reasonable, even laudable, intention. Learning from experience and research is the fundamental rationale for policy analysis. Some degree of routinisation in social policy is also legitimate and desirable on the grounds of cost effectiveness, resource efficiency and maximising the benefits of interventions. Similarly, common or minimum delivery standards reinforce the status of services as shared rights, and potentially reduce unfair discrimination based on discretion. However there is an important difference between, on the one hand, a common floor of guaranteed citizenship rights and, on the other, indiscriminate uniformity and a lack of responsiveness to varying conditions and individual circumstances: while 'standardisation may impose a floor on performance it may also impose a ceiling' (Goitein, 2015: 62). A more nuanced, sensitive and empathetic relationship between service providers and users is required to assist people to change their lives, and this must be reflected in policy development and evaluation. 
The misapplication of SIBs is expressed and embedded in a core misconceptualisation in their terminology. For example, the finality implied by the term 'outcomes' misunderstands how transformative interventions give rise to reactions and 'effects'. A transformational social policy does not succeed by producing some final nor fixed end state but cultivates capability for dealing more effectively with challenges. This involves equipping people with a dynamic set of skills, resources and competencies which help individuals and communities to respond effectively to dynamic contingencies. For example, an effective education system cultivates pupils' capacity for independent thinking and their continuing ambition and ability to learn. Such capacities and dispositions are not measured by possession of certificates, the ability to absorb and regurgitate information nor even the mastery of technical skills, important though these may be (Tarvis and Aranson, 2007). Such an impoverished Gradgrindian conception of educational 'outcomes' leads to policies designed around pass rate targets and incessant testing. This approach encourages teachers and schools to protect themselves against criticisms or potential dismissal by game playing, such as 'teaching to the test' to maximise pass rates, or 'creaming and parking' - where efforts are focused on those pupils most likely to pass at the expense of those in greatest need of support. One SIB which exemplifies the practice of creaming and parking is the Caritas Perspektive programme aimed at reducing unemployment among asylum seekers and migrants in Bern, which only selects applicants deemed to have suitable employment potentialv. SIBs exemplify the hazard of misguided measurement, as 'investors need metrics that they can easily measure and assess for achievement risk, and service providers need metrics that they can evidence' (Ronicle et al, 2016: iv). Such examples reaffirm the point that identifying 'outcomes' and measures of 'success' are as much political as technical processes

SIBs might be a valid approach to funding services for technical interventions which address simple, discrete and apolitical issues (Townsend, 1976). Liebman (2011) argues that SIBs are only suitable for conditions which have (among other things) a readily identifiable population, a distinct intervention and clear criteria to assess impact. However the most egregious social problems are not like this. Rather they are complex, multidimensional, multi-layered (with micro-, meso-, and macro-level dimensions) and contentious. In the effort to reconcile incentives for private investors with actual social problems, SIBs refashion these complex conditions in terms of measurable performance metrics, simplifying and distorting them in 
the process. Indeed, their advocates boast that 'Social Impact Bonds are less complex and multi-dimensional than poverty and the social problems they are designed to tackle' (Dean et al, 2016: 3). However, it is not only ineffective but damaging to treat complex issues as if they were simple and amenable to technical fixes, or to treat only those aspects of them which can be so simplified (Joy and Shields, 2013). The idea that an issue can be reframed so that intervention effects can be measured on a standard scale is a crude technocratic idea, which SIBs exemplify and then monetise.

Transformative social policies have multiple functions, and their ultimate purpose is to enable diffuse holistic and multidimensional changes which enhance capability and improve wellbeing. Cultivating these resources and competencies requires adjusting an actor's opportunity structure, and this involves a holistic transformation in their social environment and individual context. Consequently, designing social policies and evaluating interventions are inescapably political processes, as they involve conceptions of the 'good society' and addressing the power dynamics which inhibit or facilitate moving towards this (Bovaird, 2014; Galbraith, 1997). Simplifying complex conditions and normative problems into 'depoliticised' technical inputs and outcomes is the very epitome of ideology: when a singular conception of 'normality' becomes unquestioned (Cooper et al, 2016). The first complexity which is eliminated in this process is the voice and perspective of service users (Warner, 2013: 308).

\section{Commodification and Financialisation of Social Policy}

The misapplication and over-extension of SIBs beyond their viable capacity requires explanation. One reason for the popularity of SIBs is that they shift responsibility for the design and delivery of welfare policy from the state. In this respect SIBs exemplify the political philosophy that the role of government is not to develop and deliver social and public services but to purchase or broker them from private and third sector organisations (Whitfield, 2015). SIBs recommodify what were previously public services and are an expression of the general financialisation of social policy and of everyday life (Breen, 1997; Polanyi Levitt, 2013). Financialisation describes a process where the principles of market transactions and associated mechanisms become central organising values, resulting in a 'financial[ly] leavened existence... shaping the values of polity and economy' (Martin, 2002: 3). Financialisation involves the penetration of financial criteria and issues into what were previously non-economic areas, and transforms non-monetary social relationships, such as 
those central to social policy, into commercial ones (Sinclair, 2013). Increasing and pervasive financialisation goes unnoticed in a 'market society' dominated by principles which treat social relations as adjuncts to financial exchanges (see Polanyi, 1944: 60; 1947). This can lead to the hubristic over-extension and misapplication of narrow economic thinking. This is taken to its illogical extreme by the Freakonomics brand, which cuts through the Gordian knot of inconvenient social complexity by supposing that what matters to shape social interactions is creating the right incentives and then letting markets operate to produce the desired results (Levitt and Dubner, 2005). Closely associated with this ideology is the neo-liberal project to deregulate the real financial sector while simultaneously individualising the protection required against the risks this sector poses for citizens (Hully, 2014; Taylor-Gooby and Zinn, 2005).

It is important to highlight this underpinning ideology of SIBs. Similarly, SIBs reflect the fallacy that only that which can be directly observed and measured is real and important, and the belief that 'all state funding is investment on which there must be a calculable return' (Hammersley, 2016). Associated with this mind-set is the redefinition of citizens and public service users as 'customers'. In many areas of social policy this is an egregious and compound error. SIBs do not confer 'consumer sovereignty' upon service users. First of all, if there is a 'consumer' at all in this case it is whoever commissioned or contracted the intervention (i.e. the private or philanthropic financier - underwritten by public support); the service user is at best a client. Secondly, many welfare service users have no effective choice over suppliers (Gray, 2014). More fundamentally, many welfare service users would not choose to regard themselves as 'customers', although some are compelled to behave as such through the imposition of quasi-market mechanisms. For example, users of respite care in the UK tend to regard their relationship with care providers as more pastoral than pecuniary, but are increasingly denied this preference and find these relationships financialised as a result of the marketisation or outright privatisation of provision (Henderson et al, 2018).

SIBs are therefore a further step in the transformation of services previously provided as citizens' rights into contracts between organisations. It is not necessarily the case that citizenbased services are better (nor worse) than commercialised ones, but the tenor of the interaction between provider and client is altered when defined by markets and money (Deci 
and Ryan, 1985). Financialising the relationships within social welfare provision by committing stakeholders to bottom line delivery transforms what ought to a supportive and nurturing relationship into pecuniary transactions (Joy and Shields, 2016). If Economic concepts and terminology are to be applied to every realm of social policy, then one which is relevant to SIBs is 'externality' - a cost imposed on parties not directly involved in a transaction. This describes the effect of SIBs upon service users. For example, one diagrammatic representation of the principal stakeholders and 'Organizational structure of a SIB' lists these as government, intermediaries (i.e. bond-issuing organisation), investors, service providers, and evaluators (Warner, 2013: 305). Service users are conspicuous by their absence from this list. In the end, SIBs are not accountable to services users - which is one of their principal limitations as transformational responses to complex problems. There are also blurred accountability relationships and potentially collusive interests between the third party agencies which commission SIBs and the investors which finance them. The dependence of these intermediary facilitators upon such resources raises questions about their independence and whose interests they prioritise.

\section{Complex Social Policies and User Participation}

Social policies which receive public funding or which impact upon the wellbeing of citizens must be evaluated. The challenge is to do this effectively while respecting the agency of services users as citizens. This raises the attribution problem mentioned earlier, i.e. the difficulty of distinguishing between what causes and what is merely associated with an effect; and in the case of complex inter-agency interventions, assigning credit for specific results to particular partners. One popular response to this problem is to propose a 'theory of change' which postulates a cause-and-effect or input-outcome sequence to guide action, and specify relevant indicators and formative and summative performance measures (Pawson and Tilley, 2004). This approach is especially favoured by those who hope that policy lessons can be transferred across different settings and contexts (Bovaird, 2014).

In theory (although not in practice) the 'black box' approach to intervention ostensibly enabled by SIBs dispenses with a theory of change by funding initiatives on the basis of outcomes irrespective of how these are achieved. This aspect of SIBs should be recognised: an a priori theory of change is not appropriate for truly complex multi-dimensional problems or service needs (such as urban regeneration, supporting young people leaving care, etc.) nor 
for social systems which maintain well-being (such as providing long-term care for frail elderly people). While there will be a vision of the intended destination to be achieved in such cases, the route to this cannot be fixed and specified in detail beforehand, but must be improvised and revised reflexively in relation to changing conditions and service users' preferences and evolving capabilities. To overcome the sustained neglect or systematic marginalisation that contributes to urban decline or social exclusion requires prolonged effort and resources to transform the opportunities available to those experiencing these conditions (Power and Tunstall, 1995). Collaborative policy making empowers actors to develop in a way that imposing interventions upon them to meet predetermined outcomes does not.

Part of the background to the current interest in SIBs and related payment-by-results interventions has been criticisms levelled at conventional Fordist welfare systems (Jessop, 2013). In this approach governments developed a variety of complicated systems to address troubling social conditions which were actually fluid and complex. The inevitable disjuncture between the complexity of these issues and the inadequate response led to limited, misconceived or failed interventions, which generated discontent and demands for reform.

Complexity means dealing with 'instability, irregularity, difference and disorder' (Stacey, 1996: xix-xx). Simon's (1962) original outline of the principles of complexity involved four propositions, each of which is relevant to the development and evaluation of social policy and efficacy of SIBs. Firstly, complex systems are characterised by emergence, i.e. properties 'which are not to be understood by reductionist analysis of the systems into lower order components' (Byrne, 1997). A classic example is consciousness, which is neither reducible to, nor apparent within, brain cells. Similarly, organisations, such as corporations and welfare institutions, have collective qualities and cultures which are distinct from their constituent members. This irreducible and generative quality leads to the other features which characterise complex systems.

Simon's second and third principles may be considered together: complex systems are nonlinear, so that small changes in starting conditions or interventions can have large and unexpected effects; and such systems involve feedback loops. The non-linear nature of complex adaptive systems means that the sequence or even the occurrence of particular results are unpredictable (Bovaird, 2014: 17). However, complex systems may have tendencies towards 'strange attractors' which increase the likelihood of certain states 
occurring and which set broad outer limits for possible states of dynamic equilibrium. The SIB developed to fund mental health care provision in New South Wales illustrates some of these qualities, as mental illness encompasses a range of conditions and behaviours influenced by interactions between individual social, bio-medical, environmental and behavioural factors (Social Ventures Australia, 2017).

There are two important implications of these points for policy makers and evaluators which are particularly pertinent to SIBs. The first is that in a complex system - such as the outcomes of transformative interventions - future events cannot be controlled nor known fully in advance. The second is that step-by-step analytical reasoning and linear planning from actions to consequences is untenable, except for the very short term (Stacey, 1996: 349). Although it might be possible for transformative social policies to move a complex and - what was described in the Introduction as a 'wicked' - condition towards an evolving direction of travel, operationalising 'SMART' targets in advance to trigger payments is untenable; i.e. those which are specific, measurable, attainable, relevant and time-bound.

Simon's fourth proposition about complex systems is that they can generate spontaneous order from unplanned and unco-ordinated interactions. One implication of this for policy development and analysis is that between saying, on the one hand, that we have no idea what outcomes a policy will produce and, on the other, demanding an unattainable level of precision, it is possible to estimate the general direction relative tendency of different interventions and modes of delivery. However, problems arise when we are required to go beyond this and measure 'impact' in a more exact way, as SIBs require. This can lead policy makers and evaluators to focus on that which can be accurately measured and impose upon such factors an inappropriate and invalid (often quantitative) precision. This is why SIBs do violence to the service user's perspective and 'leave the clients voiceless' (Warner, 2017). Social policy interventions are human interactions and these are notoriously difficult to predict let alone operationalize and direct.

Dealing with and operating effectively in complex adaptive systems requires a different mindset and skills from those proposed by randomised control trial enthusiasts and the simpler advocates of evidence-based policy. Central to this is the willingness and ability to try to understand interactions between agents and their respective subjective meanings (Weber, 1978: 7). Because co-production and engaging fully with service users' subjective experiences 
and preferences are central requirements, effective policy development and evaluation should be iterative and participatory processes, adapting and responding to service users' preferences and needs (Beresford, 2018; Birrell and Gray, 2018: 77)

\section{Conclusion}

The more reflective supporters of SIBs acknowledge that they are 'neither a panacea nor a guarantee - a new form of contract does not magically produce the dogged, determined, adaptive delivery that we know is a prerequisite for creating transformational change' (North, 2016). However it would be more reassuring if the enthusiasm of the UK government and some of the other heavyweight backers of SIBs was similarly tempered by such realism (Loxely and Puzyreva, 2015: 8). Without this there is a danger that SIBs, or other recommodified policy mechanisms, will continue to be rolled out and developed without considering their implications for service users and citizens - or rather people who have been transformed into process components and outcome indicators.

The current unwarranted enthusiasm for SIBs illustrates one of the limitations of evidencebased policy, at least as it has been promoted in the UK. There is insufficient robust evidence to justify the attention and resources they are receiving and 'the jury is still out with respect to the effectiveness of SIBs' (Ronicle, et al, nd). The basis for enthusiasm for SIBs is not empirical but ideological. The attraction of SIBs is the seemingly plausible narrative they offer - the promise of a 'win-win-win' outcome - with improved social services at reduced public expense generating private profits (Warner, 2013: 310). In the absence of evidence that they are more effective in addressing social needs, they are a success of advertising and marketing rather than substance. As such they exemplify the tenor of the times, as the narrative they spin has become plausible due to the dominance of commodification and 'Great Financialization' within social policy and society more generally (Polanyi Levitt, 2013). SIBs are therefore a symptom of a deeper condition - where market principles and practice have become norms shaping everyday life. However, this hegemony is being questioned, as shown by the current crisis and critique of conventional economics, and the widespread debate about the principles of a good society (e.g. Akerlof and Shiller, 2015; Welby, 2015). A critique of SIBs is therefore more than a merely technical appraisal, but part of the necessary effort to rehumanise social policy and reclaim spheres of social life which should lie beyond the scope of the market. 


\section{References}

Akerlof, G.A. and Shiller, R.J. (2015) Phising for phools: the economics of manipulation and deception. New Haven: Princeton University Press.

Beresford, P. (ed) (2018) Social Policy first hand: an international introduction to participatory social welfare. Bristol: Policy Press.

Birrell, D. and Gray, A.M. (2018) 'Outcomes-based approaches and the devolved administrations', in Needham, C, Heins, E. and Rees, J. (eds) Social Policy Review 30. Bristol: Policy Press.

Blamey, A. and Mackenzie, M. (2007) 'Theories of change and realistic evaluation: peas in a pod or apples and oranges?' Evaluation, 13 (4): 439-455.

Bovaird, (2014) 'Attributing Outcomes to Social Policy interventions: "Gold Standard" or "Fool's Gold" in public policy and management?' Social Policy \& Administration. 48 (1): 1-23.

Breen, R. (1997) 'Risk, recommodification and stratification', Sociology, 31 (2): 473-489.

Bridges Fund Management (2017) 'HCT Group supports local authorities with innovative "payment by results" travel training programme'.

http://www.bridgesfundmanagement.com/hct-group-supports-local-authorities-innovativepayment-results-travel-training-programme/ (accessed $31^{\text {st }}$ October 2017).

Byrne, D. (1997) 'Complexity theory and social research', Social Research Update, Issue 18 http://sru.soc.surrey.ac.uk/SRU18.html (accessed 25 ${ }^{\text {th }}$ March 2017).

Carter, E. (2016) 'Living up to the hype? the application of social impact bonds in the UK', Belfast: Social Policy Association Annual Conference.

Carter, E. and FitzGerald, C. (2018) 'We should ask three big questions about SIBs', Policy Innovation Research Unit, $8^{\text {th }}$ May - http://blogs.Ishtm.ac.uk/piru/2018/05/08/we-shouldask-three-big-questions-about-sibs/ (accessed 28 ${ }^{\text {th }}$ July 2018).

Carter, E. and Whitworth, A. (2016) 'Work activation regimes and well-being of unemployed people: rhetoric, risk and reality of quasi-marketization in the UK Work Programme', Social Policy \& Administration, 51 (5): 976-816.

Centre for Public Impact (2016) Social Impact Bonds: how private finance can help transform public outcomes, Briefing Bulletin, $11^{\text {th }}$ September -

https://www.centreforpublicimpact.org/briefing-bulletin-social-impact-bonds/ (accessed $31^{\text {st }}$ October 2017).

Chou, N-H (2016) Investigating barriers of cross-sectoral collaboration under social impact bonds. Amsterdam: Vroije University.

Cooper, C., Graham, C., \& Himick, D. (2016) 'Social impact bonds: The securitization of the homeless', Accounting, Organizations and Society. 55, 63-82.

Davies. P, Newcomer, K. and Soydan, H. (2006) 'Government as structural context for analysis', in Shaw et al (ed) The SAGE handbook of evaluation: policies, programs and practices. London: Sage.

Dear, A, Helbitz, A, Khare, R, Lotan, R, Newman, J, Crosby Sims, G. and Zaroulis, A. (2016) Social Impact Bonds: the early years. London: Social Finance. 
Deci, E.L and Ryan, R.M (1985) Intrinsic motivation and self-determination in human behaviour. New York: Plenum.

Dowling, E. \& Harvie, D. (2014) 'Harnessing the social: state, crisis and (Big) Society', Sociology, 48(5): 869-886.

Edmiston, D. and Nicholls, A (2018) 'Social impact bonds: the role of private capital in outcome-based commissioning', Journal of Social Policy, 47 (1): 57-76.

Farnsworth, K. (2013) 'Bringing Corporate Welfare In', Journal of Social Policy, 42 (1): 1-22.

Fraser, A, Tan, S, Kruithof, K, Sim, M, Lagarde, M. and Mays, N. (2016) 'When technical and relational challenges frustrate new forms of social investment: a comparative analysis of four recent SIBs.' Belfast: Social Policy Association Annual Conference.

Fuertes, V. and Lindsay, C. (2015) 'Personalization and street-level practice in activation: the case of the UK's Work Programme', Public Administration, 94 (2), 526-541.

Galbraith, J. K (1997) The good society: the humane agenda. New York: Houghton Mifflin.

Gardiner, S, Gustafsson-Wright, E, and Manuelyan Atinc, T. (2016) 'The future of impact bonds globally: reflections recent Brookings event'.

http://www.brookings.edu/blogs/education-plus-development/posts/2016/03/24-futureof-impact-bonds-globally (accessed $25^{\text {th }}$ March 2017).

Goldacre, B. (2011) 'We should so blatantly do more randomised trials on policy', The Guardian, 14 ${ }^{\text {th }}$ May - http://www.badscience.net/2011/05/we-should-so-blatantly-do-morerandomised-trials-on-policy/ (accessed 25 ${ }^{\text {th }}$ March 2017).

Goitein, L. (2015) 'Training young doctors: the current crisis', New York Review of Books, $4^{\text {th }}$ June.

Gray, A, (2014) 'Review of Ian Greener "Public Management" (second ed)', Journal of Social Policy, 43 (2).

Grimm et al (2013) 'Social innovation: an answer to contemporary societal challenges? Locating the concept in theory and practice', Innovation: the European Journal of Social Science Research, 26 (4): 436-455.

Gustafsson-Wright, E. (2017) Impact bonds in developing countries: early learnings from the field. Washington DC: Brookings Centre for Universal Education.

Hammersley, M. (2016) 'Is there any justification for academic social science?', Discover Society, issue 32 - http://discoversociety.org/2016/05/03/is-there-any-justification-foracademic-social-science/ (accessed 25 ${ }^{\text {th }}$ March 2017).

Henderson, F, Reilly, C, Moyes, D. and Whittam, G. (2018) 'From charity to social enterprise: the marketization of social care', International Journal of Entrepreneurial Behavior \& Research, 24 (3): 651-666.

Hully, J. (2014) 'Lean and mean: how obsessive cost-cutting destroyed job security', Discover Society, $6^{\text {th }}$ May http://discoversociety.org/2014/05/06/lean-and-mean-how-obsessivecost-cutting-destroyed-job-security/ (accessed $25^{\text {th }}$ March 2017).

Jessop, B. (2013) Fordism and Post-Fordism: a critical reformulation, $5^{\text {th }}$ November: available online - https://bobjessop.org/2013/11/05/fordism-and-post-fordism-a-critical-

reformulation/ (accessed $25^{\text {th }}$ March 2017). 
Joy, M. and Shields, J. (2013) 'Social Impact Bonds: the next phase of third sector marketization? Canadian Journal of Nonprofit and Social Economy Research, 4 (2): 39-55.

Joy, M, and Shields, J. (2018) 'Austerity in the making: reconfiguring social policy through social impact bonds', Policy \& Politics, 46 (4): 681-695

Kay, L. (2016) 'Cabinet Office sets up centre of excellence to boost social impact bonds', Third Sector, 24 ${ }^{\text {th }}$ March - https://www.thirdsector.co.uk/cabinet-office-sets-centreexcellence-boost-social-impact-bonds/finance/article/1388863 (accessed $31^{\text {st }}$ October 2017).

Kohli, J, Besharov, D.J. and Costa, K. (2012) Social Impact Bonds 101: defining an innovative new financing tool for social programs -

https://www.americanprogress.org/issues/general/news/2012/03/22/11238/social-impactbonds-101/ Center for American Progress (accessed 31 $1^{\text {st }}$ October 2017)

Liebman, J. B. (2011) Social Impact Bonds: A promising new financing model to accelerate social innovation and improve government performance. Washington DC: American Progress.

Levitt, S.D. and Dubner, S.J. (2005) Freakonomics: a rogue economist explores the hidden side of everything. London: Penguin.

Levy, J.D. (2004) 'Activation through thick and thin: progressive approaches to labour market activation', in Ellison, N. et al (eds) Social Policy Review 16. Bristol: Policy Press.

Lipsky, M. (2010) Street level bureaucracy: dilemmas of the individual in public services, $\left(30^{\text {th }}\right.$ Anniversary Expanded Edition). New York: Russell Sage Foundation.

Loxley, J. and Puzyreva, M. (2015) Social impact bonds: an update. Winnipeg: Canadian Centre for Policy Alternatives.

Martin, R. (2002) The financialisation of everyday life. Philadelphia: Temple University Press.

May, T. (2017) 'The shared society: Prime Minister's speech at the Charity Commission annual meeting', $9^{\text {th }}$ January - https://www.gov.uk/government/speeches/the-sharedsociety-prime-ministers-speech-at-the-charity-commission-annual-meeting (accessed $25^{\text {th }}$ March 2017).

McHugh, N., Sinclair, S., Roy, M.J., Huckfield, L. and Donaldson, C. (2013), Social Impact Bonds: A Wolf in Sheep's Clothing?, Journal of Poverty and Social Justice, Vol. 21 No. 3, pp. 247-257.

McHugh, N., Biosca, O. and Donaldson, C. (2017), "From Wealth to Health: Evaluating Microfinance as a Complex Intervention", Evaluation, Vol. 23 No. 2, pp. 209-225.

Morely, J. (2017) 'Dream of Social Impact Bonds should not blind us to their dangers',

Policy Innovation Research Unit, $13^{\text {th }}$ February -

https://blogs.Ishtm.ac.uk/piru/2017/02/13/dream-of-social-impact-bonds-should-not-blindus-to-their-dangers/ (accessed $25^{\text {th }}$ March 2017).

Moulaert, F. et al. (2005) 'Towards alternative model(s) of local innovation', Urban Studies, 42 (11): 1969-90. 
Mulvaney, M. and Kriegler, L. (2014) Thinking about social impact bonds in the South African context (lessons from the United Kingdom). Cornerstone Economic Research -

http://www.innovationedge.org.za/images/resources/innovative-financing-

mechanisms/Thinking\%20about\%20SIBs\%20in\%20SA\%20-

\%20Cornerstone\%20Economic\%20Research.pdf (accessed $17^{\text {th }}$ Aug. 2016)

Murray, P. and Gripper, R. (2016) A balancing act: charities and the 2016 budget. NPC, $10^{\text {th }}$ March - http://www.thinknpc.org/publications/a-balancing-act-budget-2016/ (accessed $25^{\text {th }}$ March 2017).

North, J. (2016) 'Social impact bonds: more than just a money saving measure', Pioneers Post - https://www.pioneerspost.com/news-views/20160401/social-impact-bonds-morejust-money-saving-measure (accessed $25^{\text {th }}$ March 2017).

Pasi, G. (2014) 'Challenges for European welfare systems - a research agenda on social impact bonds', Review of Applied Socio-Economic Research, 8 (2): 141-150.

Pawson, R. and Tilley, N. (2004) Realist Evaluation http://www.communitymatters.com.au/RE_chapter.pdf (accessed $25^{\text {th }}$ March 2017).

Pearce, W. and Raman, S. (2014) 'The new randomised controlled trials (RCT) movement in public policy: challenges of epistemic governance', Policy Sciences, 47 (4): 387-402.

Polanyi K. (1944) The great transformation: The political and economic origins of our time. Second Beacon paperback edition [2001]. Boston: Beacon Press.

Polanyi, K. (1947) 'Our obsolete market mentality: civilization must find a new thought pattern', Commentary 3, 109-117.

Polanyi Levitt, K. (2013) From the great transformation to the great financialization: On Karl Polanyi and other essays. London; New York: Zed Books.

Power, A. and Tunstall, R. (1995) Swimming against the tide: polarisation or progress on 20 unpopular council estates. York: Joseph Rowntree Foundation.

Radojev, H. (2016) ' “Don't expect too much from SIBS', says NPC', 10 http://www.civilsociety.co.uk/finance/news/content/21448/a_risk_that_too_much_is_bein g_expected_of_social_impact_bonds_too_soon_says_npc (accessed $25^{\text {th }}$ March 2017).

Ronicle, J, Fraser, A, Tan. S. and Erskine, C. (nd) The LOUD SIB model: The four factors that determine whether a social impact bond is launched. London: Policy Innovation Research Unit.

Ronicle, J, Fox, T. and Stanworth, N. (2016) Commissioning Better Outcomes Fund Evaluation Update Report. London: Big Society Capital https://www.bigsocietycapital.com/sites/default/files/CBO\%20report.pdf (accessed 31 ${ }^{\text {st }}$ October 2017).

Roy, M.J., McHugh, N. and Sinclair, S. (2017), Social Impact Bonds - Evidence-Based Policy or Ideology?, in Greve, B. (Ed.), Handbook of Social Policy Evaluation, Edward Elgar Publishing Ltd, Northampton, MA, pp. 263-275.

Sclar, E. (2015) 'The political economics of investment Utopia: public-private partnerships for urban infrastructure finance', Journal of Economic Policy Reform, 18 (1): 1-15.

Silverman, D. (2000) Doing qualitative research: a practical handbook. London: Sage. 
Simon, H. (1962) 'The architecture of complexity', Proceedings of the American Philosophical Society, 106 (6) - http://www.cs.brandeis.edu/ cs146a/handouts/papers/simoncomplexity.pdf (accessed 25 $5^{\text {th }}$ March 2017).

Sinclair, S. (2013), "Financial Inclusion and Social Financialisation: Britain in a European Context", International Journal of Sociology and Social Policy, Vol. 33 No. 11/12, pp. 658676.

Sinclair, S., McHugh, N., Huckfield, L., Roy, M.J. and Donaldson, C. (2014), Social Impact Bonds: Shifting the Boundaries of Citizenship, Social Policy Review 26: Analysis and Debate in Social Policy 2014, pp. 119-136.

Social Finance (nd) Impact Bond Global Database - http://sibdatabase.socialfinance.org.uk/ (accessed 31 ${ }^{\text {st }}$ October 2017).

Social Ventures Australia (2017) SVA launches Australia's first Social Impact Bond for mental health care, $5^{\text {th }}$ May - http://www.socialventures.com.au/news/sva-launches-australiasfirst-social-impact-bond-mental-health-care/ (accessed 31 ${ }^{\text {st }}$ October 2017).

Stacey, R.D. (1996) Strategic management and organizational dynamics. London: Pitman.

Tan, S, Fraser, A, Giacomantonio, C, Kruithof, K, Sim, M, Lagarde, M, Disley, E, Rubin, J, Mays, N. (2015) An evaluation of Social Impact Bonds in health and social care interim report. London: London School of Tropical Medicine and Hygiene, Policy Innovation Research Unit.

Tarvis, C. and Aranson, E. (2007) Mistakes were made (but not by me): why we justify foolish beliefs, bad decisions and hurtful acts. London: Pinter and Martin.

Taylor-Gooby, P. and Zinn, J. (2005) Current directions in risk research: reinvigorating the social? Canterbury: Social Contexts and Responses to Risk Network (SCARR), Working Paper 2005/8.

Thaler, R.H. and Sunstein, C.R. (2008) Nudge: improving decisions about health, wealth, and happiness. London: Yale University Press.

Townsend, P. (1976) Sociology and social policy. Harmondsworth: Penguin.

UK Government (nd) Knowledge box: developing a social impact bond -

https://www.gov.uk/guidance/social-impact-bonds (accessed 31st October 2017).

Warner, M. E. (2013) 'Private finance for public goods: social impact bonds', Journal of Economic Policy Reform, 16 (4): 303-319.

Warner, M. E. (2017) Dream of Social Impact Bonds should not blind us to their dangers. Policy Innovation Research Unit, $13^{\text {th }}$ February -

http://blogs.Ishtm.ac.uk/piru/2017/02/13/dream-of-social-impact-bonds-should-not-blindus-to-their-dangers/ (accessed 31st October 2017).

Weakley, K. (2016) ' "Social impact bond market could be with $\mathrm{f1}$ billion", says Minister', $14^{\text {th }}$ January -

http://www.civilsociety.co.uk/finance/news/content/21089/social_impact_bond_market_c ould_be_worth_1bn_says_minister (accessed $25^{\text {th }}$ March 2017).

Weber, M. (1978) Selections in Translation (edited by Runciman, W.G). Cambridge University Press. 
Welby, J. (2015) Archbishop of Canterbury's speech on "The Good Economy",' $4^{\text {th }}$ February http://www.archbishopofcanterbury.org/articles.php/5487/archbishop-of-canterburysspeech-on-the-good-economy (accessed 25 th March 2017).

Whitfield, D. (2015) Alternatives to private finance of the welfare state: a global analysis of Social Impact Bonds, pay-for-success and Development Impact Bond Projects. Adelaide: Australian Workplace Innovation and Social Research Centre.

\section{Endnotes}

\footnotetext{
' For example, the Career Connect Youth Engagement Fund in Greater Manchester https://sibdatabase.socialfinance.org.uk/

ii We are grateful for the insight provided by an anonymous Reviewer who noted that there is a tendency in the SIB literature for those who support them to come from think tanks, third sector organisations, government agencies and corporate sponsors; and for these more favourable accounts to be published in policy documents, briefings and practical guides and manuals. Examples in this article include contributions from the Centre for Public Impact (2016), or Kohli et al (2012). In contrast, more critical discussions of SIBs are more likely to appear in academic journals. Examples cited in this article include those of Edmiston and Nicholls (2018) or Joy and Shields (2018). This is a potentially interesting example of the role of different interpretative communities and dissemination formats in framing academic and policy discourses.

iii https://sibdatabase.socialfinance.org.uk/

iv A so-called 'thick' active labour market or 'employability service is characterised by significant investment in human capital development (education and training provision), job brokering and mediation services which build effective relationships between employers and job-seekers, and support which reduces barriers to sustainable employment, such as assistance with transport costs. One SIB-funded initiative which possesses elements of such an approach is the Colour Kitchen youth training and employment initiative in Utrecht https://sibdatabase.socialfinance.org.uk/

In contrast, 'thin' work-first schemes focus on pushing benefit recipients into any form of employment as soon as possible. See Levy, 2004; Carter and Whitworth, 2016)

${ }^{v}$ https://sibdatabase.socialfinance.org.uk/
} 